\title{
INFORMATION MANAGEMENT IN ARCHITECTURE - OFF-GRID CAPABLE COMPLEX
}

\author{
Anna Brudnicka and Adam Rybka \\ Rzeszow University of Technology \\ Faculty of Civil and Environmental Engineering and Architecture \\ Al. Powstańców Warszawy 12, 35-959 Rzeszow, Poland
}

\begin{abstract}
Energy efficiency, share of renewable energy sources in the country's energy balance and reduction of pollutant emissions are priorities in the development of modern economy. A significant part of the energy generated is absorbed by the construction sector. It refers not only to the planning stages and the formation of buildings. It has also a special importance in their exploitation. Energy from renewable sources is not fully used and properly managed. The study of the changes in the spatial structure and economic performance of small cities reduced to develop ideas for development mechanisms and tools that can be used by local authorities to stimulate and control the processes taking place in the cities. It is necessary to implement programs supporting the energy development of self- sufficient cooperating settlements complexes. Desirable off-grid capable neighborhoods comprised of renewable energy, power positive homes, storage of energy, water and waste recycling systems must be supported by information resource management. The villages using technology and sensors to monitor living patterns, energy obtain and use, storage efficiency, send data to the cloud of units to learn from each other. Knowledge sharing and operational effectiveness has made effective information management a growing priority for construction industry. The findings provide a much needed practical view of the complexities of information management, highlighting three core categories classed as drivers, constraining factors and barriers. Integrated infrastructure enable units witch surplus energy possibility to help communities with deficiency of energy. Further research is also required to develop appropriate measurement criteria for determining the effectiveness of strategies. The concept combines a variety of innovative technologies, where the outputs of one system are inputs of another. The article is an attempt to show the general trend of the possible development and popularization of self-sufficient settlements. It will contribute to improve energy supply in areas with poorly developed energy infrastructure.
\end{abstract}

\section{KEYWORDS}

Architectural Design, Renewable Energy, Integrated Infrastructure

\section{INTRODUCTION}

\subsection{Background and Purposes}

Growing populations, number of homes and a lot of new appliances have caused the growth of energy demand. Increasing share of renewable energy sources in energy balance contributes to the improvement of the efficiency of using and saving energy resources, improvement of the environment by reducing emission of pollution to the atmosphere, soil and water. The fast-paced development of power systems necessitates smart grids to facilitate real-time control and monitoring. Future smart grids are expected to have reliable, efficient, secured, and cost-effective.

\subsection{Scope and Focus of this Work}

The concept is to develop a off-grid capable neighborhoods where the resources will be used in a closed loop. Starting with planning stages and the formation of buildings, through exploitation, maintenance and final demolition and recycling. The units will use the technology and sensors to monitor living patterns, energy use and efficiency, and send that data to the cloud to similar villages to learn from each other. Already existing technologies will be applied into an integrated system of information management. 


\section{OVERVIEW OF OFF-GRID COMPLEX}

\subsection{Smart Grid Drivers}

The "smart grid" is a term used to describe advanced electrical distribution system that has a capability to balance electrical loads from diverse, alternative energy generation sources. A special feature is the capacity to store electrical energy. The factors driving development of smart grid are varied. Increase in the use of wind, solar and other renewable sources to produce energy it become operational challenges (Prasad 2014).

\subsection{Description of the Complex}

The eco-efficient solutions are improvements in conventional design, but still have negative impact to environment. Regenerative design is a part of sustainable development, but it is not the same as sustainable design. Sustainability it's a process that endures without degradation, but it does not regenerate itself. It is like plastic bottle - sustains; a plant - regenerates. Sustainable design has to task to provide elementary human needs without environmental degradation (Reed 2006). Regenerative design goes further. The concept combines a variety of innovative technologies, such as energy positive homes, renewable energy, energy storage, food production, water management and waste to reduce systems.

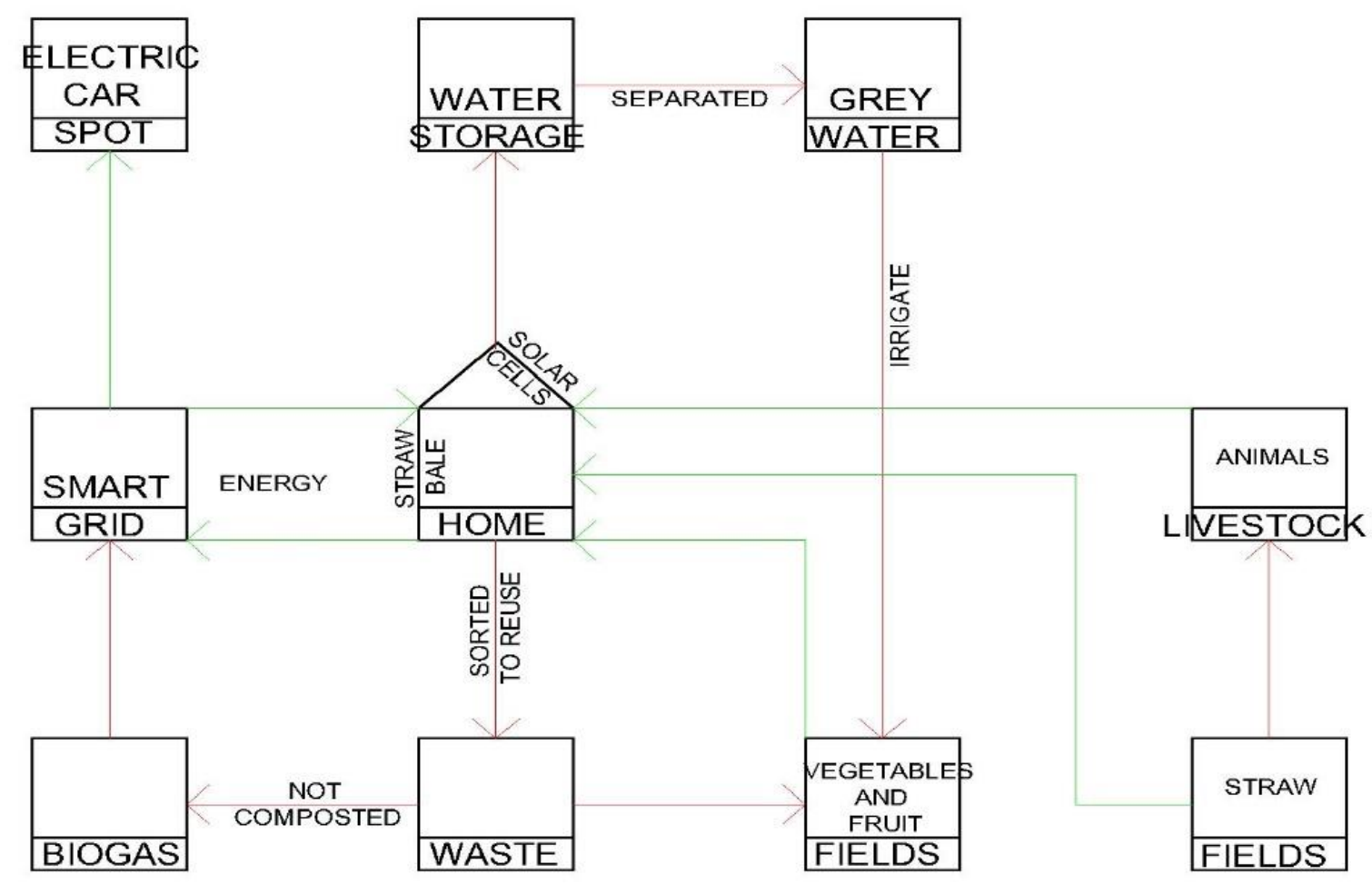

Figure 1. Regenerative System (Brudnicka 2017) ${ }^{1}$

\footnotetext{
${ }^{1}$ Figure 1-archive of Anna Brudnicka
} 
Household waste is restored into different categories for recycling. The not compostable waste is used in the biogas facility. Compost becomes food for livestock and fields. The seasonal gardens produces fruit and vegetables for the home consumption. Livestock is also provided food source.

The roofs of houses are collecting the rainwater and stores it in water storage. The water production from the biogas facility is also added to the water storage. Gray water is separated and used to irrigate the fields. Clean water is distributed to the households.

The solar cells on house roofs provides energy for the homes and distributes to the smart grids. The biogas plant energy is also added to the smart grid. The smart grid distributes energy to the settlements and to electric car spots.

Straw - bale construction is a building method that uses bales of straw as structural elements, building insulation, or both. Advantages of this system includes the renewable natural straw, low cost, easy availability, naturally fire - retardant and high insulation value (Rybka 2017). Straw - bale technology is characterized by zero carbon footprint, possibility of composting, $\lambda=0.052$ to $0.080 \mathrm{~W} / \mathrm{mK}$ (Minke 2015). The applied technology allows to reduce the construction costs of building a fully functional home, while also meeting functional and aesthetic expectations of modern society (Rybka 2018).

\section{KEY COMPONENTS - COORDINATION FRAMEWORK}

\subsection{Targets of the System}

Coordination is the system by which distributed control elements are made to cooperate to solve a problem (in this case, off-grid capable neighborhoods). Exploring methods for measuring and potentially predicting system interia associated with effectiveness of units may provide key information useful in researches of system reliability. In addition, such methods would be useful in the development of joint planning tools for purposes of enhancing understanding of infrastructure interdependencies (U.S. Department of Energy 2014). Therefore, there is a need to integrate a common platform with dispersed units and smart grid. Proper energy management will allow to optimal balancing of energy demand and supply. The most important targets of system are:

- energy security,

- safety,

- minimum environmental footprint,

- robustness (resilience and reliability),

- finance ability,

- flexibility (optionality and extensibility).

\subsection{Elements of Analysis and Optimization}

To manage of smart grid, in secure, reliable and scalable way, utilities must be equipped in communication network management system to a distributed data center. Cloud computing is an emerging technology advocated for energy management. That applications are one of the most useful techniques for the future smart grid development (Bera 2015).

Table below illustrates set of elements useful to compare, and to formulate and to solve various optimization problems, based on objectives and constrains. 
Table 1. Selected elements of Data Cloud Computing

\begin{tabular}{|c|c|c|}
\hline $\begin{array}{l}\text { COMPONENTS } \\
\text { AND STRUCTURES }\end{array}$ & PROPERTIES & $\begin{array}{l}\text { SYSTEM } \\
\text { QUALITIES } \\
\text { (TARGETS) }\end{array}$ \\
\hline $\begin{array}{l}\text { - synchronized energy } \\
\text { demand and supply } \\
\text { sensing } \\
\text { - real-time monitoring } \\
\text { - early warning system } \\
\text { - energy obtain and } \\
\text { storage } \\
\text { - integrated planning of } \\
\text { development } \\
\text { - synchronized units } \\
\text { - advanced optimizing } \\
\text { controls } \\
\text { - grid integration } \\
\text { - data management } \\
\text { - micro grids } \\
\text { - coordination (central } \\
\text { and dispersed) } \\
\text { - regulatory } \\
\text { - financial resources } \\
\text { - type of consumers } \\
\text { - technology of buildings } \\
\text { (e.g. straw-bale) } \\
\text { - climatic conditions } \\
\text { - new materials }\end{array}$ & $\begin{array}{l}\text { - controllability } \\
\text { - observability } \\
\text { - tolerance of load } \\
\text { - scalability } \\
\text { - local optimization } \\
\text { - data/system/device } \\
\text { interpretation } \\
\text { - fault tolerance } \\
\text { - efficiency of energy and } \\
\text { network resources } \\
\text { - emissivity } \\
\text { - ability to regenerate }\end{array}$ & $\begin{array}{l}\text { - minimum } \\
\text { environmental } \\
\text { footprint } \\
\text { - affordability } \\
\text { - energy security } \\
\text { - safety } \\
\text { - robustness } \\
\text { - flexibility } \\
\text { - finance ability }\end{array}$ \\
\hline
\end{tabular}

\subsection{Future Research Directions}

Virtualization is one of the most efficient techniques for resource optimization and cost reduction. Cloud computing can be implemented in the form of different strategies of development off-grid complexes. Requires a supporting communication infrastructure and protocols to maximize benefits. Table 2 shows some of basic mappings use in analysis and optimization of off-grid complex. It illustrates tracing impact of synchronized units on an energy security of region. It is possible to do for any set of elements.

Table 2. Tracing Synchronized Units Impact on Energy Security

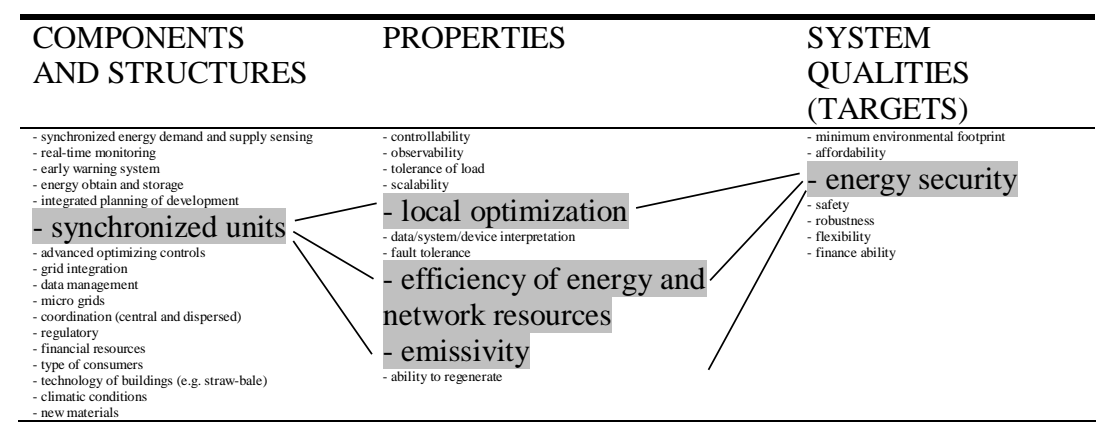

\section{CONCLUSION}

This paper demonstrates changes that can be made in a coordinated way to combat climate change and carbon emission at small regional level. Energy systems characterized by minimal environmental footprint should be designed, constructed and operated. Proper system operation must be based on information management. One of the most important factors is affordability which ensures system costs and needs are 
balanced with the ability of users. An attempt to achieve a balance between the continuity of urbanization processes and the environment are the following actions:

- curry out activities directed at diversifying sources of energy in a maximum use of renewable sources,

- create favorable conditions for the emergence of intelligent Smart Grid,

- develop infrastructure to generate energy from renewable sources,

- introduce an energy management system, in particular the implementation plans for heat and electricity from the renewable sources.

This paper presents findings from an investigation into directions of development of single-family housing, focused on energy self-sufficiency. The findings highlight the significance of information management in off-grid units. They also indicate areas in which further research is required. The article presents a preliminary tool to analysis and optimization of integrated infrastructure. The model takes into account set of elements of data cloud computing. It allows to coordinate functioning off-grid unit

\section{REFERENCES}

Bera S. et al, 2015. Cloud Computing Applications for Smart Grid: A Survey. IEEE Transactions on Parallel \& Distributed Systems, Vol. 26, No. 5, pp. 1477-1494

Minke, G. et al. 2015. Podręcznik budowania z kostek słomy. Fundacja Cohabitat, Łódź.

Prasad I., 2014. Smart Grid Technology: Application and Control. International Journal of Advanced Research in Electrical, Electronics and Instrumentation Engineering, Vol. 3, Issue 5.

Reed, B., 2006. Shifting our Mental Model - "Sustainability" to Regeneration. Rethinking Sustainable Construction 2006: Next Generation Green Buildings, Sarosata, Florida

Rybka A. et al, 2018. Architecture in the process of social inclusion of homeless. E3S Web of Conferences, Vol. 49, No. 00093.

Rybka, A. et al. 2017. Straw bale technology in the contex of designing modern permacultural system. In: Regeneracja Architektury. Ed. A. Janucha-Szostak, M. Banach. Wydawnictwo Politechniki Poznańskiej, Poznań.

U.S. Department of Energy, 2014. Grid Architecture. Pacific Northwest National Laboratory Richland, Washington. 